University of Michigan Law School

University of Michigan Law School Scholarship Repository

1909

\title{
The Federal Constitution is Not Violated by a State Law Compelling One Accused of Crime to Testify Against Himself
}

\author{
James H. Brewster \\ University of Michigan Law School
}

Available at: https://repository.law.umich.edu/articles/1304

Follow this and additional works at: https://repository.law.umich.edu/articles

Part of the Constitutional Law Commons, and the Courts Commons

\section{Recommended Citation}

Brewster, James H. "The Federal Constitution is Not Violated by a State Law Compelling One Accused of Crime to Testify Against Himself." Mich. L. Rev. 7 (1909): 242-4.

This Response or Comment is brought to you for free and open access by the Faculty Scholarship at University of Michigan Law School Scholarship Repository. It has been accepted for inclusion in Articles by an authorized administrator of University of Michigan Law School Scholarship Repository. For more information, please contact mlaw.repository@umich.edu. 
The Federal Constitution is Nor Violated by a State Law Compelling One Accused of Crime to Testify Aganst Himself.-At first sight this proposition seems a little startling, but a careful consideration of the opinion of Mr. Justice Moopy in the recent case of Twining et al. v. The State of New Jersey, 29 Sup. Ct. R. 14, probably will satisfy most readers that it is sound.

The plaintiffs in error were convicted of a criminal offense in the trial court, the judgment of conviction was affirmed in the court of errors and appeals of New Jersey, and they assign for error that by the mode of proceedings adopted at the trial they were denied the right of an accused person not to be compelled to testify against himself, which they maintain is a right secured to them by the Constitution of the L'nited States.

On the trial the accused called no witnesses, nor did they themselves testify, although the law of the state gave them the right to do so. The law of New Jersey permitted an unfavorable inference against the accused to be drawn by the jury from their failure to testify in denial of the evidence which tended to incriminate them, and the trial court in substance so instructed the jury. Assuming that what was done at the trial was an infringement of the privilege against self-incrimination-though not deciding this point-the court proceeds to examine the question whether such a law violates the 14th Amendment, either by abridging the privileges or immunities of citizens of the United States or by depriving persons of their life, liberty or property without due process of law.

Admitting that much might be said in favor of the view that the privilege was guaranteed against state impairment as a privilege and immunity of national citizenship, Mr. Justice Moopy shows that the decisions of the Supreme Court have foreclosed that view.

It was not argued by plaintiffs in error that they are protected by that part of the $5^{\text {th Amendment which provides that no "person } * * * \text { shall }}$ be compelled in any criminal case to be a witness against himself," for they recognize that the first ten Amendments are not operative on the states, but they do contend that this privilege is one of the fundamental rights of national citizenship, placed under national protection by the I4th Amendment, and that the "privileges and immunities of citizens of the United States" protected against state action by this Amendment include those fundamental personal rights which were protected against national action by the first 
eight Amendments. These contentions, Mr. Justice Moovy holds, are answered by the decisions of the Supreme Court: that the distinction between national and state citizenship and their respective privileges drawn in the Slaughter-House Cases, 16 Wall. 36 , has come to be firmly established: that "if, then, it be assumed, without deciding the point, that an' exemption from compulsory self-incrimination is what is described as a fundamental right belonging to all who live under a free government, and incapable of impairment by legislation or judicial decision, it is, so far as the states are concerned, a fundamental right inherent in state citizenship, and is a privilege or immunity of that citizenship only": that the contention that the safeguards of personal rights which are enumerated in the first eight articles of Amendment, though they were by those Amendments originally secured only against national action, are among the privileges and immunities of citizens of the United States and protected against state action by the 14th Amendment, while supported by weighty arguments (see the opinions of Mr. Justice FIELD in O'Neil v. Vermont, I44 U. S. 323, 36̈r, and of Mr. Justice HarLaN in Marzuell v. Dow, 176 U. S. $58 \mathrm{r}, 606$ ) is no longer open; it having been definitely settled that "the I4th Amendment did not forbid the states to abridge the personal rights enumerated in the first eight Amendments, because those rights were not within the meaning of 'the clause 'privilege's and immunities of citizens of the United States."

It is held further that this exemption from compulsory self-incrimination is not required by due process of law. It is clear as matter of history that the practice of compulsory self-incrimination existed for centuries after Magna Charta (WIGMORE, EvidencE, $\$ 2250$ ), and by an historical survey the, opinion in this case shows that during the time when the meaning of due process was in a formative state the exemption from compulsory self-incrimination was not considered to be inherent in due process of law, but, on the other hand, a right independent and outside of due process. "Even if," the opinion concludes, "the historical meaning of due process of law and the decisions of this court did not exclude the privilege from it, it would be going far to rate it as an immutable principle of justice which is the inalienable possession of every citizen of a free government. Salutary as the principle may seem to the great majority, it cannot be ranked with the right to hearing before condemnation, the immunity from arbitrary power not acting by general laws, and the inviolability of private property. The wisdom of the exemption has never been universally assented to since the days of Bentham, many doubt it today, and it is best defended not as an unchangeable principle of universal justice, but as a law proved by experience to be expedient. See WIGMORE, EvTDENCE, §225I. * * * The states had guarded the privilege to the satisfaction of their own people up to the adoption of the I4th Amendment. No reason is perceived why they cannot continue to do so."

In dissenting, Mr. Justice HARLAN affirms that no former decision of the Supreme Court requires the present decision: a view somewhat inconsistent with his opinion in Maxtell v. Dow, $176 \mathrm{U}$. S., at page 615. He 
quotes from Mr. Justice Bradley's opinion in Boyd v. United States, II6 L. S. $616,631,633$, that "any compulsory discovery by extorting the party's oath, or compelling the production of his private books and papers, to convict him of crime, or to forfeit his property, is contrary to the principles of a free government. It is abhorrent to the instincts of an Englishman; it is abhorrent to the instincts of an American. It may suit the purposes of despotic power, but it cannot abide the pure atmosphere of political liberty and personal freedom."

Nevertheless, it may still be true that there are very important personal rights, those named, for example, in the first eight Amendments, that are not necessarily "privileges and immunities of citizens of the United States" within the meaning of the 14 th Amendment. Maxwell v. Doze, I76 U. S. 581. 